\title{
Towards amorphous solution-processed small-molecule photovoltaic cells by design
}

\author{
Tham Adhikari, ${ }^{\mathrm{a}}$ Jean-Michel Nunzi, ${ }^{\mathrm{a}, \mathrm{b}, *}$ Olivier Lebel ${ }^{\mathrm{c}, *}$ \\ ${ }^{a}$ Department of Chemistry, Queens University, Kingston, Ontario, Canada \\ ${ }^{\mathrm{b}}$ Department of Physics, Engineering Physics and Astronomy, Queens University, Kingston, Ontario, Canada \\ ${ }^{c}$ Department of Chemistry and Chemical Engineering, Royal Military College, Kingston, Ontario, Canada
}

*Corresponding Author. E-mail address: nunzijm@queensu.ca (J.M. Nunzi); Olivier.Lebel@rmc.ca (O. Lebel).

\begin{abstract}
Organic photovoltaic cells incorporating a homogeneously blended amorphous active layer were fabricated using a novel glass-forming squarylium cyanine derivative (SQ-glass) as donor, and both a previously reported glass-forming diketopyrrolopyrrole (DPP-glass) and the benchmark $\mathrm{PC}_{61} \mathrm{BM}$ as acceptors. Whereas devices with DPP-glass always yielded an amorphous active layer, devices with PCBM could be either fully amorphous, or phase-segregated with crystalline PCBM, depending on processing conditions. Amorphous devices yielded efficiencies ranging up to $0.41-0.44 \%$, while the efficiency of devices with crystalline PCBM reached up to $0.56 \%$, which corresponds to only a $18 \%$ increase relative to a fully amorphous active layer. Although phase-segregated active layers are known to show a higher efficiency, this difference is smaller than anticipated, and is mitigated by the absence in amorphous films of various defects common in their polycrystalline counterparts.
\end{abstract}

Keywords: Organic photovoltaic cells, Bulk heterojunction, Homogeneous blend, Molecular glass, Squarylium cyanines materials such as crystallinity, miscibility, interaction parameter and solubility in processing solvents. The D/A blend ratio, processing conditions and post-processing

\section{Introduction}

Organic photovoltaics constitute a promising alternative energy technology that can address future energy issues in an environmentally friendly way. ${ }^{1}$ Organic photovoltaic (PV) cells utilize organic semiconducting small molecules or polymers that can directly convert sunlight into electricity. ${ }^{2-5}$ Organic PV (OPV) cells possess several potential advantages over conventional inorganic PV cells such as easy processability, device flexibility and cost effectiveness. In particular, solution- processed OPV cells are promising for future low-cost power production using simple and flexible devices that can be processed on a large scale using techniques such as roll-to-roll or inkjet printing. ${ }^{6}$ Solutionprocessed OPV cells have been demonstrated to be capable of reaching power conversion efficiencies above $10 \%$ based on a nanocomposite between a donor and an acceptor material called bulk heterojunction. ${ }^{7}$

The role of bulk heterojunctions in OPV cells is to promote exciton dissociation at the interface between electron donor and acceptor domains, followed by efficient charge separation and transport to the electrodes by charge diffusion in the interpenetrating donor and acceptor networks. ${ }^{8-9}$ To achieve this, it is crucial for the donor and acceptor domains to be properly segregated in small domains. ${ }^{10}$ Solid-state morphology is one of the critical factors determining the performance of OPV cells. ${ }^{11} \mathrm{~A}$ bi-continuous interpenetrating network morphology with a characteristics length scale equivalent to the exciton diffusion length $(\sim 10 \mathrm{~nm})$ is required to increase the donor/acceptor interfacial area that leads to reduced unfavorable recombination. ${ }^{12-13}$ The active layer morphology strongly depends on the various parameters of treatments also play an important role for influencing the blend morphology. ${ }^{14}$

Low bandgap polymers are the most commonly used donors in OPV cells, and possess several properties that make them appealing to use in OPV cells, including large absorption, large hole mobility, and adequately tuned HOMO and LUMO levels. ${ }^{1,15}$ However, polymers also carry certain disadvantages, including a high synthesis cost, difficult purification methods, and batch-to-batch variations in molar mass and defect density. Small-molecule materials are an appealing alternative to polymers, because of their easy synthesis and purification, well-defined structure, monodispersity, and tunability of optoelectronic properties. ${ }^{16-}$

19 However, not every small-molecule material used in organic photovoltaics can be deposited from solution. Most acceptor materials are small molecules, mainly fullerene derivatives,$^{20}$ and can be readily processed from solution. On the other hand, several small-molecule donors show limited solubility, and as a result, deposition must be achieved by vacuum thermal deposition, which requires a high temperature and is not compatible with flexible PV cells. ${ }^{7,21-22}$ However, recent advances in solution-processed smallmolecule donors has resulted in PV cells with impressive power conversion efficiencies (PCEs) up to $8 \%$. $^{7}$

Independently of whether the donor is a polymer or a small molecule, the morphology of the active layer must still be thoroughly controlled to yield phase-segregated donor and acceptor domains of an appropriate size. However, the nucleation of molecular crystals can occur in solution depending on the interplay of non-covalent interactions 
between the conjugated moieties or the peripheral groups, along with external parameters such as temperature or concentration, resulting in incomplete film coverage with high surface roughness. ${ }^{23}$ Furthermore, small molecules tend to crystallize rapidly during solvent and thermal annealing to yield films of poor quality with polycrystalline small domains separated by grain boundaries, which act as electron traps and limit the long-range transport of electrons. ${ }^{24}$

Previously, our group showed that amorphous materials could be successfully used as the acceptor in organic PV cells by using both glass-forming perylenediimide (PDI) ${ }^{25}$ and diketopyrrolopyrrole (DPP) ${ }^{26}$ derivatives as acceptors with the benchmark donor polymer P3HT in solution-processed organic PV cells. Furthermore, the PV cell performance of the glass-forming DPP derivative was compared with the performance of an analogous crystalline derivative and was found to yield PCE values $20 \%$ to $50 \%$ larger depending on the conditions, up to a maximal PCE of $2.50 \%$. These glassforming acceptors were conveniently synthesized by reacting the corresponding precursors with mexylaminotriazine derivatives bearing reactive functional groups. These mexylaminotraizine building blocks show outstanding glassforming ability and high kinetic stability towards crystallization, and their glass transition temperatures $\left(\mathrm{T}_{\mathrm{g}}\right)$ can be tuned by modifying their molecular structures. ${ }^{27-29}$ The materials functionalized with glass-forming mexylaminotriazine derivatives can remain indefinitely in the amorphous state at working temperatures, which preserves their optical and electronic properties. ${ }^{30-31}$

Although a completely amorphous and homogeneously blended active layer is believed to lead to a vastly decreased performance compared to a bulk heterojunction with properly segregated donor and acceptor domains, it would nonetheless mitigate the impact of molecular structure and processing conditions on film morphology. Furthermore, such an approach would avoid most pitfalls associated with bulk heterojunctions, including uneven crystalline domain distribution, domains of inappropriate size, grain boundaries, and mismatched domains. ${ }^{32-33}$

In this report, a glass-forming donor material based on a squarylium cyanine moiety (SQ-glass) was synthesized and characterized, and incorporated in PV cells with both previously described glass-forming acceptor DPP-glass and the benchmark $\mathrm{PC}_{61} \mathrm{BM}$. While fully amorphous and homogeneously blended active layers could be obtained with both DPP-glass and PCBM, bulk heterojunctions with crystalline PCBM domains could also be obtained depending on the processing conditions, thereby allowing to compare both active layer morphologies. Maximal efficiencies of 0.42 $\%$ were obtained with DPP-glass, and $0.52 \%$ with PCBM. Interestingly, phase segregation in PV cells with PCBM only increased efficiency by $18 \%$. The results reported herein show that charge transport is possible in the amorphous state, and a homogeneously blended active layer can show performances comparable to that of phase-segregated bulk heterojunctions.

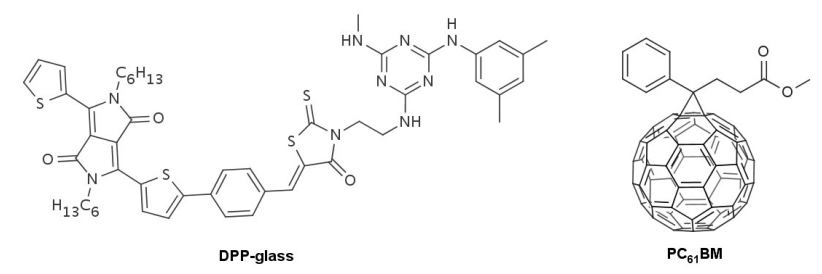

\section{Experimental}

\subsection{Materials}

2,4-dichloro-6-(N-methylphenylamino)-1,3,5-triazine, ${ }^{34}$ 1-(2hydroxyethyl)-2,3,3-trimethylindolenine bromide ${ }^{35}$ and DPPglass were synthesized according to literature procedures. ${ }^{26}$ [6,6]-phenyl- $\mathrm{C}_{61}$-butyric acid methyl ester $\left(\mathrm{PC}_{61} \mathrm{BM}\right)$ as electron acceptor was purchased from Rieke Metals. Molybdenum oxide used as hole transport layer was purchased from Alfa Aesar. Zinc Oxide $(\mathrm{ZnO})$ as electron transporting material was synthesized by the sol-gel method reported in the literature. ${ }^{36}$ Indium tin oxide (ITO) glasses used as substrates were purchased from Luminescence Technology Corporation, with ITO film thickness $135 \pm 15 \mathrm{~nm}$, and sheet resistance $15 \Omega \mathrm{sq}^{-1}$. All other solvents and reagents used herein were purchased from commercial sources and used as received without further purification. Glass transition temperatures were determined with a TA Instruments 2010 Differential Scanning Calorimeter calibrated with indium at a heating rate of $5^{\circ} \mathrm{C} / \mathrm{min}$ from 30 to $250{ }^{\circ} \mathrm{C}$. Values were reported as the half-height of the heat capacity change averaged over two heating runs. FTIR spectra were acquired with thin films cast from $\mathrm{CH}_{2} \mathrm{Cl}_{2}$ on $\mathrm{KBr}$ windows using a Perkin-Elmer Spectrum 65 spectrometer. NMR spectra were acquired on either a 400 $\mathrm{MHz}$ Bruker AV400 or on a $300 \mathrm{MHz}$ Varian Oxford spectrometer. UV-Visible absorption spectra were acquired using a Hewlett-Packard 8453 spectrometer or an Olid ${ }^{\circledR}$ HP8452 Diode Array Spectrometer. Luminescence was measured with a USB2000-Ocean Optics spectrometer. XRD data were obtained using an Xpert Pro Philips powder X-ray diffractometer with a cobalt $\mathrm{x}$-ray tube $\left(\kappa=1.78 \mathrm{~A}^{0}\right)$, an iron filter, a graphite crystal monochromator, a proportional counter detector, a 0.50 divergence slit and a $0.25 \mathrm{~mm}$ receiving slit. Current density-voltage $(\mathrm{J}-\mathrm{V})$ measurements were carried out using a Keithley 4200-SCS in the dark and under illumination.

\subsection{Synthesis}

2.2.1. Synthesis of 2-chloro-4-(N-methylphenylamino)-6pyrrolininyl-1,3,5-triazine 1 .

To a solution of 2,4-dichloro-6-(N-methylphenylamino)1,3,5-triazine $(13.3 \mathrm{~g}, 51.9 \mathrm{mmol})$ in acetone $(50 \mathrm{~mL})$ in a round-bottomed flask equipped with a magnetic stirrer was added $\mathrm{K}_{2} \mathrm{CO}_{3}(7.18 \mathrm{~g}, 51.9 \mathrm{mmol})$, then the mixture was cooled down to $0{ }^{\circ} \mathrm{C}$ and a solution of pyrrolidine $(4.34 \mathrm{~mL}$, 
$3.69 \mathrm{~g}, 51.9 \mathrm{mmol})$ in acetone $(100 \mathrm{~mL})$ was added dropwise. The mixture was stirred $2 \mathrm{~h}$ while warming up to ambient temperature, at which point $\mathrm{Et}_{2} \mathrm{O}$ and $\mathrm{H}_{2} \mathrm{O}$ were added. Both layers were separated, then the organic layer was washed with $\mathrm{H}_{2} \mathrm{O}$ and brine, dried over $\mathrm{Na}_{2} \mathrm{SO}_{4}$, filtered, and the volatiles were removed under vacuum. The crude product was triturated in hot hexanes, then collected by filtration to yield, after drying, $8.20 \mathrm{~g}$ pure compound $1(28.3 \mathrm{mmol}, 54 \%)$. $\mathrm{T}_{\mathrm{m}}$ $108{ }^{\circ} \mathrm{C}$; FT-IR $\left(\mathrm{KBr} / \mathrm{CH}_{2} \mathrm{Cl}_{2}\right) 3059,3037,2970,2954,2925$, 2875, 1601, 1578, 1558, 1487, 1458 1448, 1399, 1344, 1314, 1293, 1281, 1259, 1238, 1180, 1166, 1153, 1094, 1073, 1025, $970,939,911,861,816,799,784,765,696,642,614 \mathrm{~cm}^{-1}$; ${ }^{1} \mathrm{H}$ NMR (400 MHz, DMSO- $\left.d_{6}, 363 \mathrm{~K}\right) \delta 7.40\left(\mathrm{t},{ }^{3} J=7.8 \mathrm{~Hz}\right.$, $2 \mathrm{H}), 7.33\left(\mathrm{~d},{ }^{3} J=7.8 \mathrm{~Hz}, 2 \mathrm{H}\right), 7.26\left(\mathrm{t},{ }^{3} J=7.8 \mathrm{~Hz}, 1 \mathrm{H}\right), 3.44$ $(\mathrm{m}, 7 \mathrm{H}), 1.88\left(\mathrm{t},{ }^{3} \mathrm{~J}=6.3 \mathrm{~Hz}, 4 \mathrm{H}\right) \mathrm{ppm} ;{ }^{13} \mathrm{C} \mathrm{NMR}(75 \mathrm{MHz}$, DMSO- $\left.d_{6}\right) \delta 168.4,164.7,162.6,143.9,129.1,127.0,126.6$, 46.6, 46.5, 38.3, 38.2, 25.1, 24.9 ppm; HRMS (ESI, $\mathrm{MNa}^{+}$) calcd. for $\mathrm{C}_{14} \mathrm{H}_{16} \mathrm{ClNaN}_{5}$ m/e: 312.0986 , found: 312.0987 .

\subsubsection{2-(N-methylphenylamino)-4-piperazinyl-6-pyrrolidinyl- 1,3,5-triazine 2 .}

2-Chloro-4-(N-methylphenylamino)-6-pyrrolidinyl-1,3,5triazine 1 (10.0 g, $34.5 \mathrm{mmol})$ and piperazine $(29.7 \mathrm{~g}, 345$ $\mathrm{mmol})$ were dissolved in THF $(100 \mathrm{~mL})$ in a round-bottomed flask equipped with a magnetic stirrer and a water-jacketed condenser, then the mixture was refluxed $18 \mathrm{~h}$. After cooling down to ambient temperature, the volatiles were concentrated under vacuum, then $\mathrm{CH}_{2} \mathrm{Cl}_{2}$ and $1 \mathrm{M}$ aq. $\mathrm{NaOH}$ were added, and both layers were separated. The organic layer was recovered and extracted with $1 \mathrm{M}$ aq. $\mathrm{HCl}$. The aqueous layer was recovered, neutralized with $\mathrm{NaOH}$ pellets to $\mathrm{pH}>12$, and extracted with $\mathrm{CH}_{2} \mathrm{Cl}_{2}$. The organic layer was dried over $\mathrm{Na}_{2} \mathrm{SO}_{4}$, filtered, and the solvent was removed under vacuum to yield, after thorough drying, $9.84 \mathrm{~g}$ compound 2 (29.0 mmol, $84 \%) . \mathrm{T}_{\mathrm{g}} 56{ }^{\circ} \mathrm{C}$; FT-IR $\left(\mathrm{KBr} / \mathrm{CH}_{2} \mathrm{Cl}_{2}\right)$ 3402, 3057, 3037, 2960, 2926, 2868, 1601, 1541, 149, 1477, 1457, 1445, $1390,1343,1313,1281,1245,1222,1207,1157,1100,1027$, $1005,965,911,861,807,786,765,735,696,625 \mathrm{~cm}^{-1} ;{ }^{1} \mathrm{H}$ NMR (300 MHz, $\left.\mathrm{CDCl}_{3}\right) \delta 7.34(\mathrm{~m}, 4 \mathrm{H}), 7.12\left(\mathrm{t},{ }^{3} J=7.0 \mathrm{~Hz}\right.$, $1 \mathrm{H}), 3.68\left(\mathrm{t},{ }^{3} J=4.7 \mathrm{~Hz}, 4 \mathrm{H}\right), 3.49(\mathrm{~m}, 7 \mathrm{H}), 2.84\left(\mathrm{t},{ }^{3} J=4.7\right.$ $\mathrm{Hz}, 4 \mathrm{H}), 1.86(\mathrm{~m}, 4 \mathrm{H}), 1.70$ (br s, $1 \mathrm{H}) \mathrm{ppm} ;{ }^{13} \mathrm{C}$ NMR $(75$ $\left.\mathrm{MHz}, \mathrm{CDCl}_{3}\right) \delta 165.1,164.8,163.6,145.2,128.4,126.5$, 125.0, 45.9, 43.9, 41.6, 37.3, 25.1 ppm; HRMS (ESI, $\mathrm{MH}^{+}$) calcd. for $\mathrm{C}_{18} \mathrm{H}_{26} \mathrm{~N}_{7}$ m/e: 340.2244 , found: 340.2248 .

\subsubsection{Synthesis of Squarylium cyanine 3 .}

1-(2-hydroxyethyl)-2,3,3-trimethylindolenine bromide (2.61 $\mathrm{g}, 9.20 \mathrm{mmol})$, squaric acid $(1.00 \mathrm{~g}, 4.38 \mathrm{mmol})$ and quinoline $(1.09 \mathrm{~mL}, 1.19 \mathrm{~g}, 9.20 \mathrm{mmol})$ were dissolved in toluene/1-butanol 1:1 (125 $\mathrm{mL})$ in a round-bottomed flask equipped with a magnetic stirrer, a Dean-Stark trap and a water-jacketed condenser, then the mixture was refluxed $18 \mathrm{~h}$. After cooling down to ambient temperature, the volatiles were evaporated under vacuum, then $\mathrm{Et}_{2} \mathrm{O}$ was added, and the resulting precipitate was decanted. The residue was redissolved in minimal $\mathrm{CH}_{2} \mathrm{Cl}_{2}$, poured into $\mathrm{Et}_{2} \mathrm{O}$, then the precipitate was collected by filtration and washed with $\mathrm{H}_{2} \mathrm{O}$ and $\mathrm{Et}_{2} \mathrm{O}$ until the effluent was colorless to yield, after drying, $2.05 \mathrm{~g}$ compound 3 (4.23 mmol, 97\%). $\mathrm{T}_{\mathrm{m}}>300{ }^{\circ} \mathrm{C}$ (dec.); FT-IR $\left(\mathrm{KBr} / \mathrm{CH}_{2} \mathrm{Cl}_{2}\right)$ 3346, 3054, 2961, 2924, 2870, 1572, 1494, 1455, 1431, 1354, 1279, 1241, 1171, 1099, 1055, 1020, $969,930,835,814,782,753,696,682 \mathrm{~cm}^{-1} ;{ }^{1} \mathrm{H}$ NMR $(400$ $\left.\mathrm{MHz}, \mathrm{CDCl}_{3}\right) \delta 7.49\left(\mathrm{~d},{ }^{3} \mathrm{~J}=7.3 \mathrm{~Hz}, 2 \mathrm{H}\right), 7.31(\mathrm{~m}, 4 \mathrm{H}), 7.14$ $\left(\mathrm{t},{ }^{3} J=7.3 \mathrm{~Hz}, 2 \mathrm{H}\right), 5.89(\mathrm{~s}, 2 \mathrm{H}), 4.33(\mathrm{br} \mathrm{s}, 2 \mathrm{H}), 4.16\left(\mathrm{t},{ }^{3} \mathrm{~J}=\right.$ $5.4 \mathrm{~Hz}, 4 \mathrm{H}), 3.77\left(\mathrm{t},{ }^{3} \mathrm{~J}=5.4 \mathrm{~Hz}, 4 \mathrm{H}\right), 1.69(\mathrm{~s}, 12 \mathrm{H}) \mathrm{ppm} ;{ }^{13} \mathrm{C}$ NMR $\left(100 \mathrm{MHz}, \mathrm{CDCl}_{3}\right) \delta 180.7,177.8,169.7,142.7,141.3$, 129.2, 129.0, 127.6, 123.4, 121.9, 110.6, 86.3, 57.7, 48.6, 45.9, $26.4 \mathrm{ppm}$; UV-Vis (DMF): $\lambda_{\max }$ (ع) $641 \mathrm{~nm}$ (143000); HRMS (ESI, $\mathrm{MNa}^{+}$) calcd. for $\mathrm{C}_{30} \mathrm{H}_{32} \mathrm{NaN}_{2} \mathrm{O}_{4}$ m/e: 507.2254 , found: 507.2258 .

\subsubsection{Synthesis of SQ-glass 4.}

To a solution of N,N'-carbonyldiimidazole (1.25 g, 7.68 $\mathrm{mmol})$ in dry DMF $(25 \mathrm{~mL})$ in a dry flask equipped with a magnetic stirrer was added squarylium cyanine 3 (1.24 g, 2.56 mmol) in small portions at ambient temperature under nitrogen atmosphere. Once the addition was complete, the mixture was stirred $18 \mathrm{~h}$ at ambient temperature under nitrogen. The mixture was poured in $\mathrm{H}_{2} \mathrm{O}$, and the resulting precipitate was collected by filtration and washed with $\mathrm{H}_{2} \mathrm{O}$ and $\mathrm{Et}_{2} \mathrm{O}$ until the effluent was colorless. The residue was suspended in THF $(30 \mathrm{~mL})$ in a round-bottomed flask equipped with a magnetic stirrer and a water-jacketed condenser, glass 2 (1.91 g, $5.63 \mathrm{mmol})$ was added, and the mixture was refluxed $18 \mathrm{~h}$. The volatiles were removed under reduced pressure, then $\mathrm{CH}_{2} \mathrm{Cl}_{2}$ and $1 \mathrm{M}$ aq. $\mathrm{AcOH}$ were added. Both layers were separated, the organic layer was recovered, washed with $\mathrm{H}_{2} \mathrm{O}$ and aq. $\mathrm{NaHCO}_{3}$, dried over $\mathrm{Na}_{2} \mathrm{SO}_{4}$, filtered, and the volatiles were removed under vacuum to yield, after thorough drying, $2.35 \mathrm{~g} \mathrm{SQ}$-glass 4 (1.93 mmol, $75 \%) . \mathrm{T}_{\mathrm{g}} 94{ }^{\circ} \mathrm{C}$; FT-IR $\left(\mathrm{KBr} / \mathrm{CH}_{2} \mathrm{Cl}_{2}\right)$ 3053, 2962, 2927, 2867, 1703, 1599, 1541, 149, 1457, 1390, 1344, 1283, 1233, 1185, 1099, 1066, 1020, 997, 969, 916, 835, 807, 781, 756, $736,697,684 \mathrm{~cm}^{-1}$; ${ }^{1} \mathrm{H}$ NMR (400 MHz, DMSO- $\left.d_{6}, 363 \mathrm{~K}\right) \delta$ $7.32(\mathrm{~m}, 12 \mathrm{H}), 7.13(\mathrm{~m}, 4 \mathrm{H}), 7.05\left(\mathrm{~d},{ }^{3} J=8.0 \mathrm{~Hz}, 2 \mathrm{H}\right), 6.02$ (s, 2H), $4.51\left(\mathrm{t},{ }^{3} J=4.9 \mathrm{~Hz}, 4 \mathrm{H}\right), 4.33(\mathrm{br} \mathrm{s}, 4 \mathrm{H}), 3.63(\mathrm{~m}$, $4 \mathrm{H}), 3.46(\mathrm{~m}, 22 \mathrm{H}), 3.19(\mathrm{~m}, 4 \mathrm{H}), 1.83(\mathrm{~m}, 8 \mathrm{H}), 1.79(\mathrm{~s}, 12 \mathrm{H})$ ppm; ${ }^{13} \mathrm{C}$ NMR (100 MHz, DMSO- $\left.d_{6}\right) \delta 181.9,180.0,170.3$, $165.2,164.8,163.6,154.5,145.0,142.4,141.7,128.8,128.0$, $127.9,127.6,126.2,125.3,124.4,123.8,122.1,109.4,86.8$, $60.9,49.3,45.6,43.4,42.5,37.0,30.2,27.0,25.1$ ppm; UVVis $\left(\mathrm{CH}_{2} \mathrm{Cl}_{2}\right): \lambda_{\max }(\varepsilon) 639 \mathrm{~nm}$ (156000); HRMS (MALDI, $\mathrm{MH}^{+}$) calcd. for $\mathrm{C}_{68} \mathrm{H}_{79} \mathrm{~N}_{16} \mathrm{O}_{6}$ m/e: 1215.6363, found: 1215.6345 .

\subsection{Cyclic Voltammetry}

Cyclic voltammograms were recorded using an EG\&G Model 263 potentiostat connected with three electrodes: working electrode (glassy carbon-carbon), reference electrode $(\mathrm{Ag} / \mathrm{AgCl}$ (in $3 \mathrm{M} \mathrm{NaCl})$ ) and counter or auxiliary electrode (Pt) in $0.1 \mathrm{M}$ Tetrabutylammonium hexafluorophosphate in dichloromethane at a scan rate of $50 \mathrm{mVs}^{-1}$. Ferrocene was 
used as internal standard.

\subsection{Atomic Force Microscopy}

The morphology of SQ-glass/DPP-glass and SQ-glass/PCBM blend films was characterized using an Ambios multimode Atomic Force Microscope (AFM) in tapping mode with a 300 $\mathrm{KHz}$ resonant frequency cantilever.

\subsection{Device Fabrication and Characterization}

The devices were fabricated according to previously published procedures. ${ }^{24,37-38}$ Pre-patterned Indium tin oxide glass (ITO) substrates were cleaned consecutively in an ultrasonic bath with soapy water, distilled water, isopropyl alcohol and acetone for 15 minutes each and finally dried with air. The dried substrates were heated at approximately $100{ }^{\circ} \mathrm{C}$ for 30 minutes to improve the surface adhesion and wettability of the ITO-glass. ${ }^{39}$ The dried substrates were further cleaned with a plasma cleaner for 15 minutes. $\mathrm{ZnO}$ precursor gel was spin-coated at a rate of $3000 \mathrm{rpm}$ under ambient conditions. The glass substrates coated with $\mathrm{ZnO}$ were heated on a hot plate at $200{ }^{\circ} \mathrm{C}$ for $1 \mathrm{~h}$. The thickness of $\mathrm{ZnO}$ measured with a Sloan Dektak II profilometer was approximately 25-30 nm. Blend solutions of SQ-glass with DPP-glass or $\mathrm{PC}_{61} \mathrm{BM}$ were prepared separately in different solvents (chlorobenzene, chloroform \& toluene) in different weight ratios $(1: 1,2: 1$ and1:2) and stirred for $24 \mathrm{~h}$ at room temperature. The blend solutions were filtered through a 0.45 $\mu \mathrm{m}$ poly(tetrafluoroethylene) (PTFE) filter. The active layer was spin-coated at $1500 \mathrm{rpm}$ and annealed at temperatures ranging from 80 to $150{ }^{\circ} \mathrm{C}$ for 10,30 or 60 minutes. The thicknesses of the active layers were in the $75-85 \mathrm{~nm}$ range. The contacts with the electrodes were cleaned with a cotton stick soaked with chloroform. Finally, $5 \mathrm{~nm}$ of $\mathrm{MoO}_{3}$ and 100 $\mathrm{nm}$ of $\mathrm{Ag}$ were deposited with deposition rates of $0.2 \mathrm{~A} / \mathrm{s}$ and 1.0 $\mathrm{A} / \mathrm{s}$, respectively, on all the devices using a physical vapour deposition system (PVD) under high vacuum at a pressure of $7.6 \times 10^{-6} \mathrm{mBar}$. The active area of the devices was $0.06 \mathrm{~cm}^{2}$. The device structure and energy alignment is shown in Figure 1.

The photovoltaic parameters of the inverted cells were measured under ambient conditions using a Xenon light with an intensity of $100 \mathrm{mWcm}^{-2}$ calibrated with an AM 1.5 solar simulator, and conversion efficiencies are reported as averages for a minimum of 6 devices.

(a)

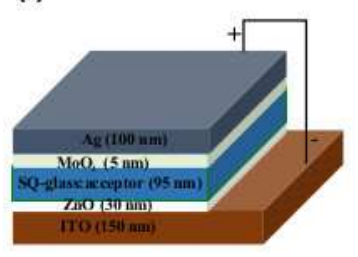

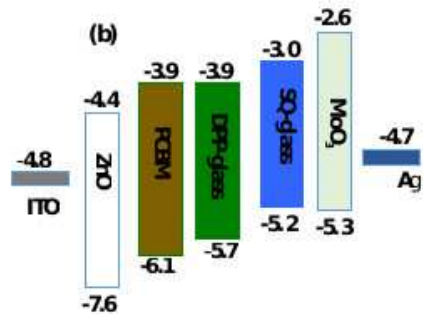

Figure 1. a) Device structure, and b) energy level alignment of photovoltaic cells incorporating SQ-glass with either DPPglass or PCBM.

\section{Results and Discussion}

\subsection{Synthesis}

While several small-molecule donors reported in the literature possess structures reminiscent of small thiophene oligomers, ${ }^{40}$ squaraines were instead selected for the current study because of their high absorption in the visible range and high stability towards oxygen, light and moisture..$^{41-44}$ While squaraines typically yield lower conversion efficiencies than oligothiophene donors, their synthesis is typically more costefficient and requires fewer synthetic steps. Because the condensation of squaric acid with tertiary anilines typically give modest yields, ${ }^{45}$ squarylium cyanine derivatives can be readily accessed by the condensation of squaric acid with 2,3,3-trimethylindolenine or 2-methylbenzothiazole derivatives in significantly higher yields. ${ }^{46}$ For this reason, a symmetrical squarylium cyanine dye bearing 2-hydroxyethyl chains to allow further substitution was used to maximize synthetic efficiency. It should be noted that to the best or our knowledge, symmetrical squarylium cyanines have yet never been used in organic photovoltaic cells, but their structural similarity with squaraines and the close similarity of their absorption spectra suggests that they should also show similar photovoltaic behavior.

It has been previously shown by our group that mexylaminotriazine derivatives with reactive functional groups can be used to bond covalently to chromophores to yield adducts that share the glass-forming ability of the mexylaminotriazine moiety. However, the presence of multiple mexylaminotriazine units results in a loss of solubility in most solvents because of their high polarity and extensive hydrogen bonding. ${ }^{47}$ For this reason, triazine derivative $\mathbf{2}$, which contains a reactive secondary amino group and no hydrogen bond donors, was synthesized from cyanuric chloride and the corresponding secondary amines (Scheme 1). It has been shown that for triazine derivatives with $\mathrm{N}$-methylated amino groups, the mexyl group was not required for glass formation, as unsubstituted phenyl groups yielded comparable glass-forming ability. ${ }^{48}$ An amino group was selected as reactive group because it can be further functionalized in amidation or carbamoylation reactions through a simple and high-yielding procedure, as previously demonstrated in our group with azo and spiropyran dyes. ${ }^{30}$

Scheme 1. Synthesis of glass precursor 2 . 


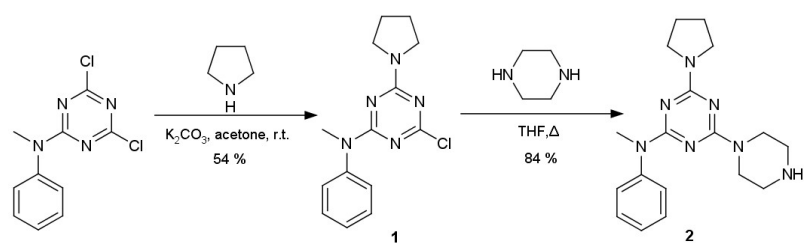

Scheme 2. Synthesis of squarylium cyanine glass (SQ-glass) 4.
4, as well as the absence of crystallization upon heating, which is an indication of the kinetic stability of the glassy phase. DSC curves of compounds $\mathbf{2}$ and $\mathbf{4}$ are shown in Figure S1 (Supporting Information). Precursor $\mathbf{2}$ indeed showed glass formation, with a glass transition temperature $\left(\mathrm{T}_{\mathrm{g}}\right)$ of 56 ${ }^{\circ} \mathrm{C}$ and no crystallization was observed upon heating, thereby confirming that compound $\mathbf{2}$ is a suitable glass-forming candidate for functionalizing chromophores. Interestingly, while glass-forming triazine derivatives with $\mathrm{N}$-methylated

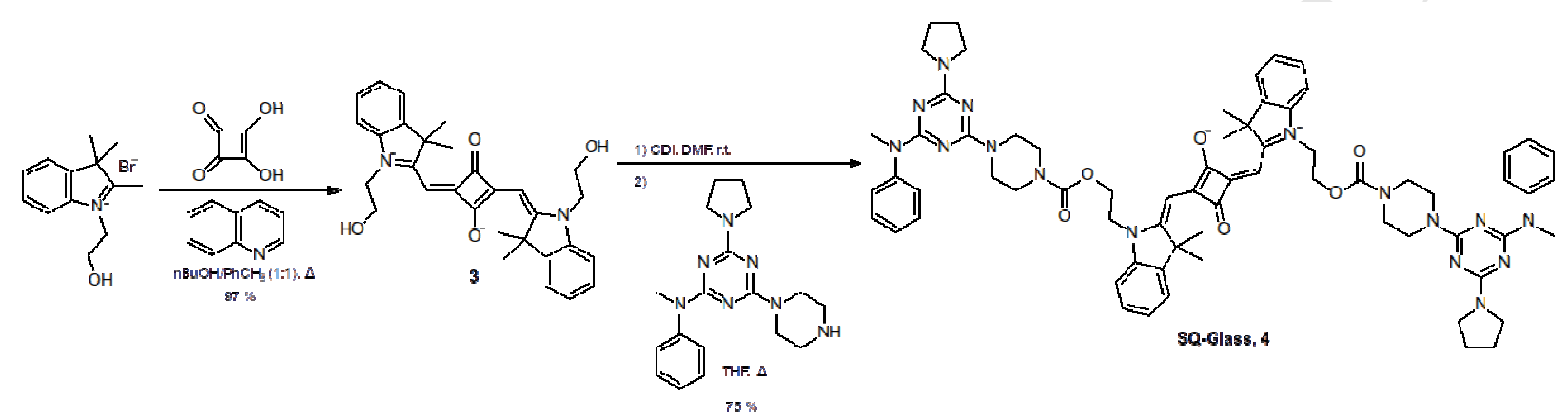

aryl groups typically show $\mathrm{T}_{\mathrm{g}}$ values that are significantly lower than their non-methylated analogues, compound 2

Squaric acid was condensed with 1-(2-hydroxyethyl)-2,3,3trimethylindolenine bromide in toluene/1-butanol (1:1) to give squarylium cyanine $\mathbf{3}$ in $97 \%$ yield, and in one synthetic step from known precursors (Scheme 2). The hydroxy groups of compound $\mathbf{3}$ could be functionalized with triazine unit $\mathbf{2}$ through a carbamoylation reaction with N,N'carbonyldiimidazole (CDI) following our previously published procedure to give adduct $\mathbf{4}$, thereafter referred to as SQ-glass, in $75 \%$ yield (Scheme 2). The product could be conveniently purified by a series of acid-base washings that completely remove the unreacted starting materials or partially reacted intermediates.

\subsection{Physical Properties}

While triazine-based glasses with no hydrogen bond donors have been previously reported and found to form stable glasses, attempts to use such building blocks to generate glass-forming chromophores had not yet been reported. Differential Scanning Calorimetry (DSC) was thus used to confirm the presence of a glass transition in compounds $\mathbf{2}$ and shows a slightly higher $\mathrm{T}_{\mathrm{g}}$ than its primary analogue, which is possibly a consequence of the more rigid piperazinyl ring. SQ-glass also shares the glass-forming properties of precursor 2, with no crystallization upon heating and a higher $\mathrm{T}_{\mathrm{g}}$ value of $94{ }^{\circ} \mathrm{C}$, which is to be expected for a compound with two triazine units.

UV-Visible absorption spectra of SQ-glass 4 , both in chlorobenzene solution and as a thin film, are shown in Figure

2a. Both spectra show a single absorption band with a small shoulder, with maxima at $640 \mathrm{~nm}$ in solution and $660 \mathrm{~nm}$ as a thin film. Not only is the absorption band red-shifted for the thin film, the band is also significantly broader, hinting at significant intermolecular interactions between squarylium cyanine moieties in the solid state. The optical band gap for SQ-glass was $2.0 \mathrm{eV}$, as determined using a Tauc plot (Figure S2). ${ }^{49}$ The emission spectrum for SQ-glass in chlorobenzene is shown in Figure 2b. SQ-glass exhibits an intense fluorescence with an emission maximum of $659 \mathrm{~nm}$ upon excitation at $550 \mathrm{~nm}$. 


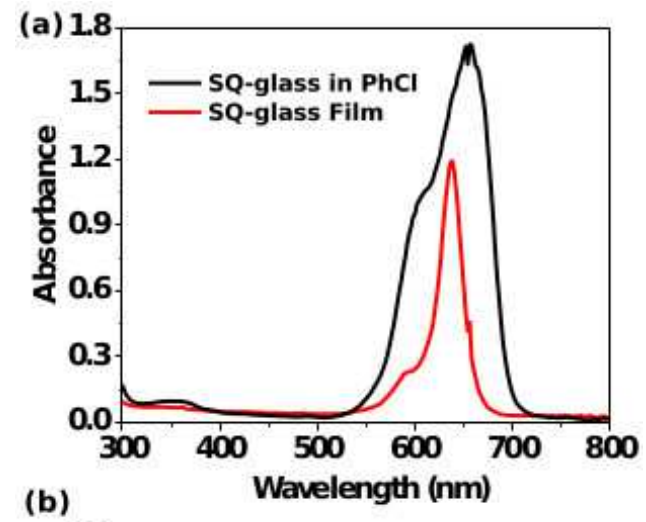

(b)

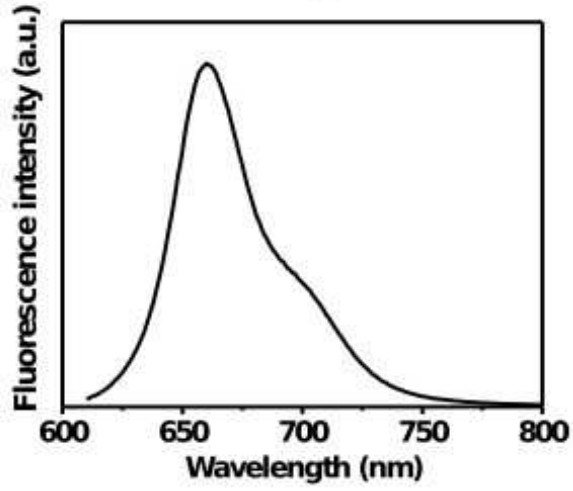

Figure 2. UV-Visible spectra of SQ-glass 4. a) Absorption spectra in chlorobenzene solution and as a thin film, and b) emission spectrum.

Electrochemical studies were carried out by cyclic voltammetry to measure the oxidation potential of SQ-glass 4 , from which it is possible to calculate the HOMO energy level (Figure S3, Supporting Information). The onset oxidation potential $\left(\mathrm{E}_{\mathrm{ox}}\right)_{\mathrm{on}}$ was observed at $0.65 \mathrm{eV}$ relative to $\mathrm{Fc} / \mathrm{Fc}^{+}$, which corresponds to a HOMO level of $-5.05 \mathrm{eV}$ by comparison to ferrocene $(-4.4 \mathrm{eV})$. As expected, no significant peak reduction was observed, showing the very weak reduction behavior of SQ-glass. With the measured HOMO level and the optical bandgap, the LUMO level was calculated to be $-3.05 \mathrm{eV}$. The HOMO and LUMO energy levels of SQ-glass are close to that of both benchmark donor polymer P3HT (-5.0 and $-3.1 \mathrm{eV}$, respectively $)^{50}$ and reported values for other squaraine derivatives. ${ }^{44,51}$

The charge carrier mobility of SQ-glass 4 was determined, because it is correlated with the PV cell performance. A high mobility is crucial for optimal performance, since a low mobility will enhance charge recombination, thereby leading to reduced photocurrent. To measure the hole mobility of SQglass, diodes with the configuration ITO/ZnO/SQglass $/ \mathrm{MoO}_{3} / \mathrm{Ag}$ were prepared, and their IV characteristics were measured (Figure S4). The hole mobility was calculated using the Mott-Gurney space-charge-limited current (SCLC) equation from the intercept of the linear fit of the SCLC region (see Supporting Information), ${ }^{52}$ to yield a value of $2.55 \times 10^{-8} \pm 0.10 \times 10^{-8} \mathrm{~cm}^{2} \mathrm{~V}^{-1} \mathrm{~s}^{-1}$. This value is relatively low, and may be due to chromophoric dilution of the squarylium cyanine moiety by the presence of two triazine units.

\subsection{Characterization of Thin Films of SQ-glass Blends with DPP- glass or PCBM}

The absorption spectra for thin films of blends of SQ-glass 4 with both DPP-glass and $\mathrm{PC}_{61} \mathrm{BM}$ in $1: 1$ weight ratios were recorded and displayed in Figure 3. For both blends, the absorption spectra correspond to that of their respective components, though a slight hypsochromic shift $(8 \mathrm{~nm})$ can be seen in the absorption band of SQ-glass in the blend with DPP-glass, whereas SQ-glass shows a bathochromic shift (3 $\mathrm{nm}$ ) when blended with PCBM.

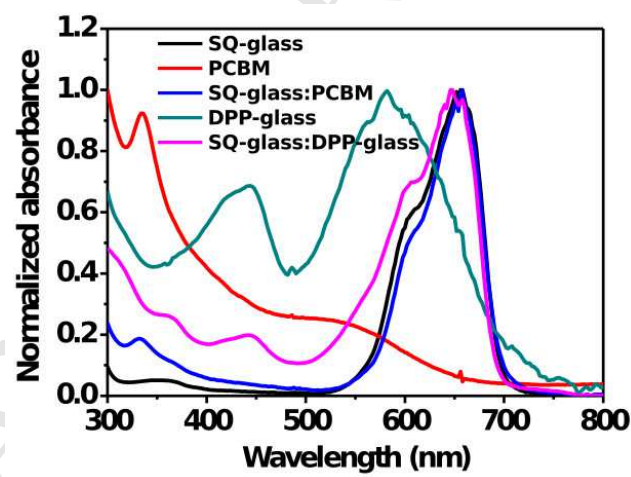

Figure 3. UV-Visible absorption spectra of SQ-glass, DPPglass, PCBM, and 1:1 blends of SQ-glass with DPP-glass and PCBM.

The photoluminescence of the blend films can also be used to study the stability of the morphology of the donor-acceptor blends. Upon intimate mixing of the donor and acceptor phases, the photoluminescence of the blend is quenched by photoinduced electron transfer. For a large-scale phase separation in the blend, the exciton diffusion length in the active layer should be beyond 10-20 $\mathrm{nm}$. If the electrons are not transferred rapidly (a few femtoseconds) within the working PV cells, the photo-generated excitons will decay to the ground state, thereby emitting photoluminescence. This is an undesirable process that results in a loss in efficiency. The electron transfer at the interface between SQ-glass 4 and both DPP-glass and PCBM was observed by photoluminescence (PL) quenching, which provides evidence of electron transfer from the photo-excited donor to the acceptor. ${ }^{53}$ Photoluminescence (PL) spectra for SQ-glass $\mathbf{4}$ and its respective blends are shown in Figure 4 . Whereas pure SQglass 4 displays a strong PL band at $670 \mathrm{~nm}$ upon excitation at $550 \mathrm{~nm}$, this PL intensity decreases by roughly $25 \%$ in a 1:1 blend with DPP-glass, and $50 \%$ in a $1: 1$ blend with PCBM. Although it is possible that this PL quenching is due to energy transfer between SQ-glass and DPP-glass, it is unlikely in the case of PCBM because it absorbs very weakly in the emission range of SQ-glass. These results show that both DPP-glass and PCBM favor exciton dissociation in the blends, with a higher rate of electron transfer with PCBM than with DPP-glass. 


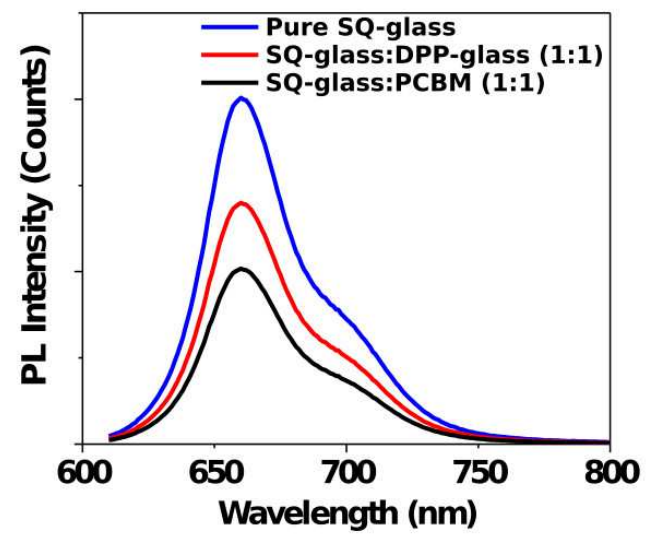

Figure 4. Photoluminescence spectra of thin films of SQglass and 1:1 blends of SQ-glass with DPP-glass and PCBM.

The crystallinity and packing behavior of films of pure SQglass 4 and blends with DPP-glass and PCBM in a 1:1 ratio were further studied by X-ray diffraction. The XRD scans for SQ-glass 4 and both blends before and after annealing at 100, 130 and $150{ }^{\circ} \mathrm{C}$ (for 30 minutes in each case) are shown in Figure 5. In the case of the blend with DPP-glass, decomposition was observed upon annealing at temperatures higher than $100{ }^{\circ} \mathrm{C}$. Only amorphous halos were observed for both SQ-glass 4 and the SQ-glass/DPP-glass blend, which confirm the amorphous nature of the films and their resistance to crystallization under the processing conditions. No sharp peaks were observed in the SQ-glass/PCBM blend before annealing and after annealing at $100^{\circ} \mathrm{C}$. However, two broad peaks at $10^{\circ}$ and $20-30^{\circ}$ emerged after annealing at 130 and $150{ }^{\circ} \mathrm{C}$, revealing the partial crystallization, and consequently phase segregation, of PCBM.
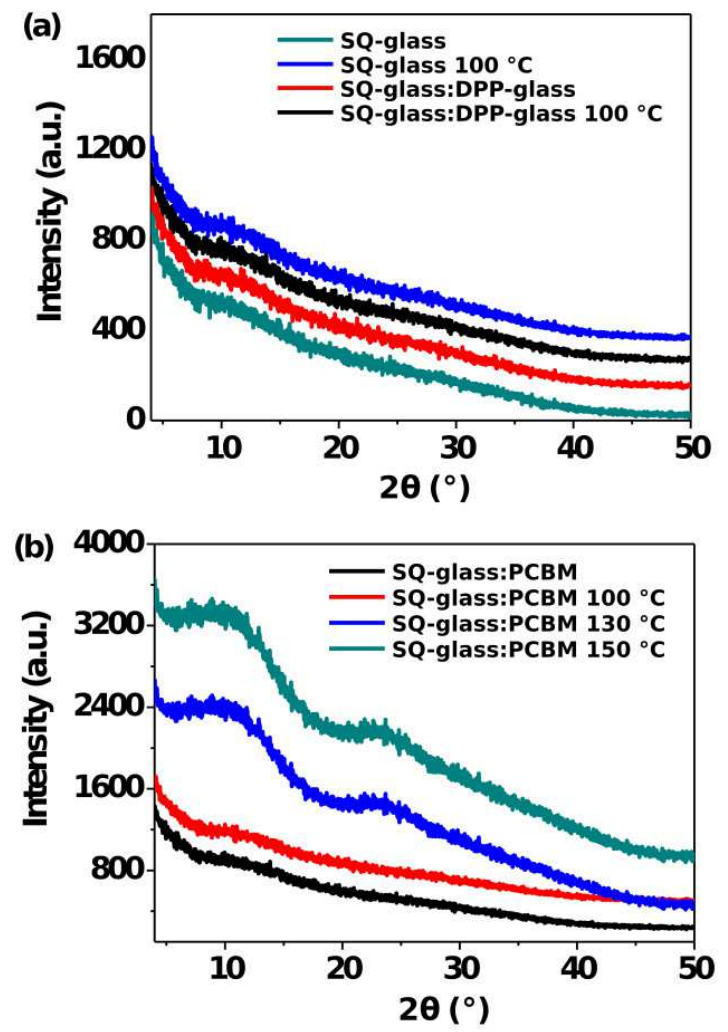

Figure 5. X-ray diffraction patterns for thin films of a) SQglass and SQ-glass:DPP-glass 1:1 deposited from chlorobenzene, and b) SQ-glass:PCBM deposited from toluene, before and after annealing at 100, 130 or 150 for 30 minutes.

Atomic force microscopy (AFM) was used to study the morphology of nanocomposite thin films to gain additional insight about film topology and phase separation at the interface. SQ-glass/DPP-glass blends were deposited from both chloroform and chlorobenzene in a 1:1 weight ratio and annealed at 80 and $100{ }^{\circ} \mathrm{C}$ for 10 minutes, respectively. Representative scans are shown in Figure 8. In all cases, it can be observed that topologically smooth films were obtained with root mean square (RMS) roughnesses ranging from 0.8 to $1.2 \mathrm{~nm}$. Thermal annealing did not cause any increase in surface roughness in either case, thereby confirming that the films remained amorphous. Small pinholes ranging from $10-20 \mathrm{~nm}$ diameter and 5-10 $\mathrm{nm}$ deep littered the surface. These pinholes are likely due to the presence of traces of water, and have been previously observed during the spin-coating of analogous compounds. ${ }^{54}$ Nonetheless, their small size makes it unlikely that these pinholes will interfere will cell performance.
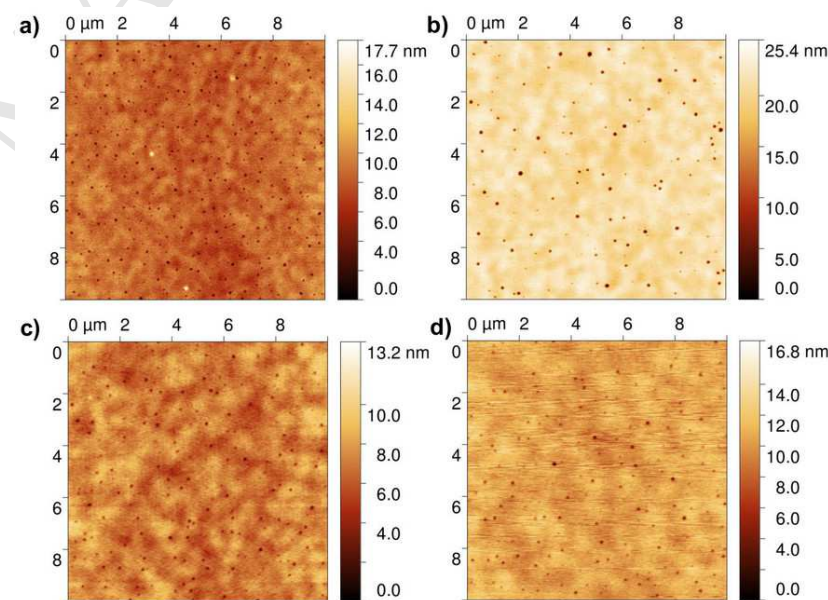

Figure 6. AFM topographic images $(10 \mu \mathrm{m} \times 10 \mu \mathrm{m})$ for SQglass:DPP glass 1:1 blend films 1:1 deposited from $\mathrm{CHCl}_{3}$ or chlorobenzene before and after annealing. a) Chloroform before annealing, b) chloroform after annealing at $80{ }^{\circ} \mathrm{C}$ for 10 minutes., c) chlorobenzene before annealing, d) chlorobenzene after annealing at $100{ }^{\circ} \mathrm{C}$ for 10 minutes.

SQ-glass/PCBM blend films were prepared similarly in a 1:1 weight ratio from chloroform, chlorobenzene and toluene. Whereas films deposited from chloroform and chlorobenzene were annealed at 80 and $100{ }^{\circ} \mathrm{C}$ for 10 minutes, respectively, films cast from toluene were annealed at 130 and $150{ }^{\circ} \mathrm{C}$ for 30 minutes in each case. At these higher annealing temperatures, crystalline peaks started appearing by XRD. AFM scans of the films deposited from chloroform and chlorobenzene (Figure 9a-d) show films with smooth surfaces 
and no obvious phase separation, with RMS roughness ranging from 1.3 to $2.2 \mathrm{~nm}$. Although films cast from toluene and annealed at $130{ }^{\circ} \mathrm{C}$ showed crystalline peaks by XRD, their surface topology shows a relatively smooth surface, with a RMS roughness of $1.0 \mathrm{~nm}$ (Figure 9e). On the other hand, annealing at $150{ }^{\circ} \mathrm{C}$ revealed a grainy film with a RMS roughness of $6.9 \mathrm{~nm}$, and with grains ranging from 500 to 700 $\mathrm{nm}$ in diameter and 10 to $20 \mathrm{~nm}$ in height, revealing clear phase segregation.
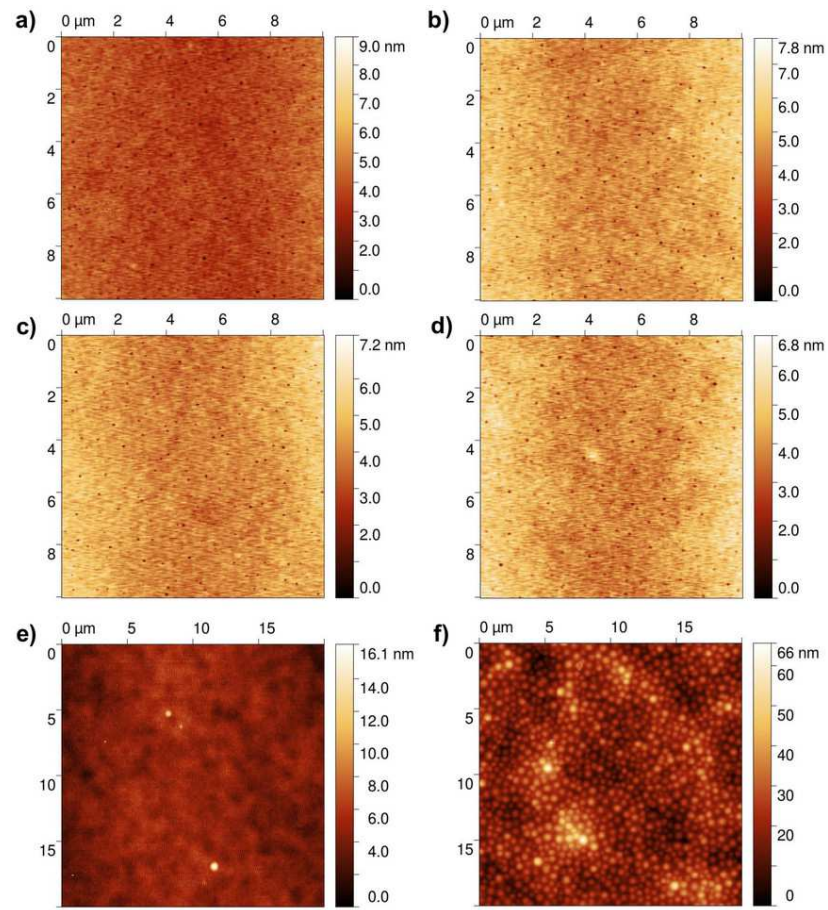

Figure 7. AFM topographic images $(10 \mu \mathrm{m} \times 10 \mu \mathrm{m})$ for SQglass:DPP glass 1:1 blend films 1:1 deposited from $\mathrm{CHCl}_{3}$, chlorobenzene or toluene before and after annealing. a) Chloroform before annealing, b) chloroform after annealing at $80{ }^{\circ} \mathrm{C}$ for 10 minutes, c) chlorobenzene before annealing, d) chlorobenzene after annealing at $100{ }^{\circ} \mathrm{C}$ for 10 minutes, e) toluene after annealing at $130{ }^{\circ} \mathrm{C}$ for 30 minutes, f) toluene after annealing at $150{ }^{\circ} \mathrm{C}$ for 30 minutes.

\subsection{Device Characterization and Performance}

Photovoltaic cells with an inverted ITO/ZnO/SQglass:acceptor/ $\mathrm{MoO}_{3} / \mathrm{Ag}$ configuration were fabricated with both DPP-glass and PCBM as acceptors. An inverted configuration was chosen because of its stability towards air and moisture, allowing to characterize device performance under ambient conditions. ${ }^{55-56}$ Indeed, unlike conventional devices that use low work-function air sensitive metals for the electron-collecting electrode and require encapsulation techniques to prevent electrode oxidation, ${ }^{57-58}$ the chargecollecting nature of the electrodes is reversed in these inverted devices, thereby allowing the use of high workfunction metals (such as Ag), and can be operated under air without any additional precautions.
Devices were fabricated incorporating both active layer components in various weight ratios $(1: 1,1: 2$, and $2: 1)$, with various solvents used for deposition (chloroform, chlorobenzene and toluene), and with various annealing temperatures and times. Films processed from chloroform were annealed at $80{ }^{\circ} \mathrm{C}$ for 10 minutes, films cast from chlorobenzene were annealed at $100{ }^{\circ} \mathrm{C}$ for 10 minutes, whereas films cast from toluene were annealed at either 100 , 130 or $150{ }^{\circ} \mathrm{C}$ for 30 minutes. It should be noted that longer annealing times failed to result in any performance improvements. The current-voltage characteristics for all devices were then measured both in the dark and under illumination with an intensity of $100 \mathrm{~mW} \mathrm{~cm}^{-2}$. The photovoltaic parameters measured for representative devices are listed in Table 1, and $\mathrm{J}-\mathrm{V}$ curves for selected devices are shown in Figure 8 (the data for all devices can be found in Tables S3-S4 and Figures S5-S7). In all cases, the current density-voltage curves of the devices in the dark (Figure 8a) show a rectification effect, indicating the formation of $p-n$ junctions in the active layer, even with both components homogeneously blended.

Significantly higher efficiencies were obtained with a 1:1 blend ratio, as it is close to an equimolar ratio of donor and acceptor. In cells with DPP-glass as acceptor, optimal performances were obtained by deposition from either chloroform or toluene, and after annealing at 80 or $100{ }^{\circ} \mathrm{C}$ for 10 or 30 minutes, respectively. These conditions yielded conversion efficiencies of $0.40-0.41 \%$. It should be noted that although the active layers are completely amorphous, thermal annealing does improve device efficiency by nearly $40 \%$, likely by eliminating residual solvent, improving both molecular packing, and promoting the formation of noncovalent intermolecular interactions in the blend, leading to improved contacts between electroactive moieties.

Unlike DPP-glass, devices using PCBM showed lower efficiency improvements (20\% or less) upon thermal annealing at lower temperatures, and chlorobenzene and chloroform yielded the best efficiencies (0.41-0.44\%). While these performances are slightly higher than that of the devices incorporating DPP-glass, they are closely similar, and although devices with SQ-glass show modest efficiencies, this seems to be a consequence of the low mobility of the SQglass itself. However, annealing at higher temperatures (130 and $150^{\circ} \mathrm{C}$ ) for 30 minutes, which has been shown to result in the crystallization and phase segregation of PCBM, resulted in higher conversion efficiencies, reaching a maximal PCE of $0.52 \%$. Another notable consequence of the crystallization of PCBM is a slight increase in the $\mathrm{V}_{\mathrm{oc}}$ of the cells from $0.42 \mathrm{~V}$ to $0.49 \mathrm{~V}$, which is a consequence of a broadening of the density of states due to the lower ordering in amorphous films, resulting in a lower $\mathrm{V}_{\text {oc }} .{ }^{59}$

Interestingly, even though proper phase segregation of the donor and acceptor components resulted in a higher performance, it only resulted in a $18 \%$ enhancement over a homogeneously blended active layer. In contrast, the packing and phase segregation of crystalline active layers can have a 
significantly deeper impact on device performance. ${ }^{60,61}$ A possible explanation to rationalize these observations is because of the glassy nature of the active layer. Since glasses are isotropic and homogeneous, they conveniently avoid the defects present in polycrystalline thin films. While polycrystalline bulk heterojunctions can lead to superior performance under ideal conditions, the presence of grain boundaries, improperly distributed donor and acceptor domains, or domains too small or too large, all contribute to losses in the efficiency. With glassy homogeneous blends, although maximal efficiencies may be lower, near-ideal conditions are comparatively easier to attain.

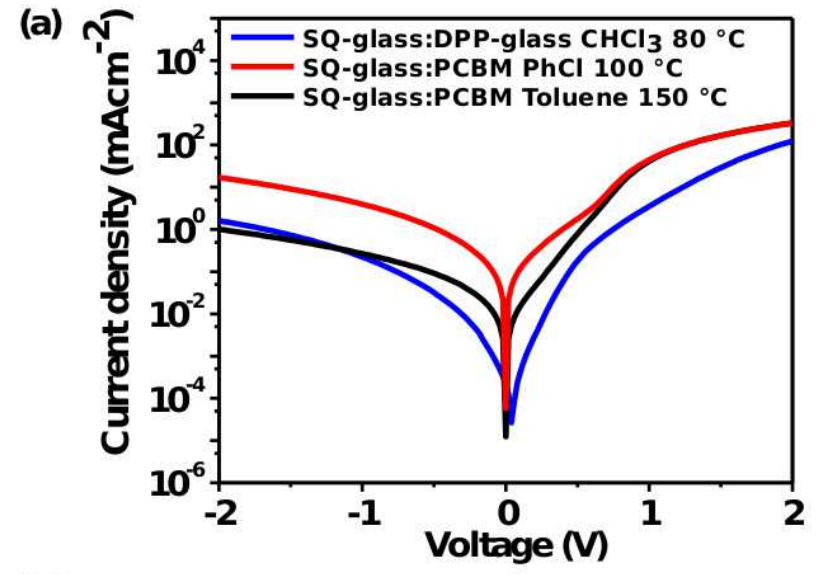

(b)

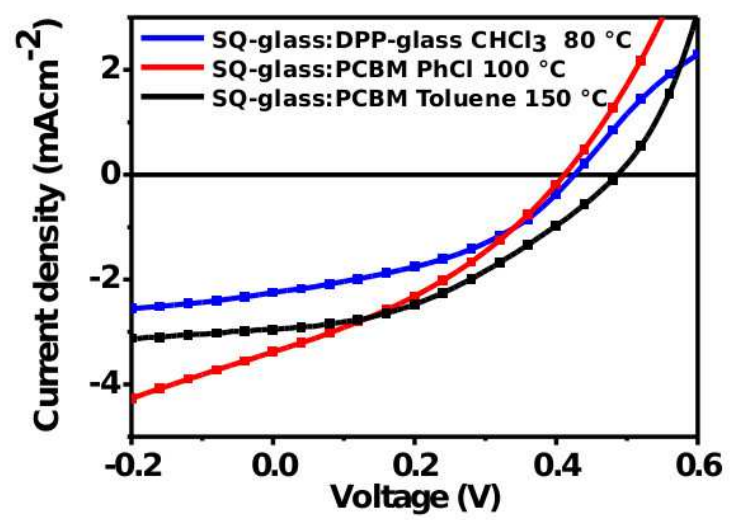

Figure 8. Current density as a function of voltage (J-V) characteristics of representative ITO/ZnO/SQ-glass:DPPglass $/ \mathrm{MoO}_{3} / \mathrm{Ag}$ or $\quad \mathrm{ITO} / \mathrm{ZnO} / \mathrm{SQ}$-glass:PCBM/ $\mathrm{MoO}_{3} / \mathrm{Ag}$ devices deposited from either chloroform, chlorobenzene or toluene a) in the dark, and b) under illumination with an irradiance of $100 \mathrm{mWcm}^{-2}$. Acceptor, deposition solvent and annealing temperature is indicated for each device.
Table 1. Photovoltaic parameters of ITO/ZnO/SQ-glass:DPPglass (1:1)/ $\mathrm{MoO}_{3} / \mathrm{Ag}$ and ITO/ZnO/SQ-glass:PCBM (1:1) $/ \mathrm{MoO}_{3} / \mathrm{Ag}$ devices under illumination with an intensity of $100 \mathrm{mWcm}^{-2}$.

\begin{tabular}{|c|c|c|c|c|c|c|}
\hline Acceptor & Solvent & $\begin{array}{l}\text { Thermal } \\
\text { Annealing }\end{array}$ & $\begin{array}{l}\mathbf{J}_{\mathrm{sc}} \\
(\mathrm{mAcm}- \\
\left.{ }^{2}\right)\end{array}$ & $\begin{array}{l}\mathbf{V}_{\mathbf{o c}} \\
(\mathbf{V})\end{array}$ & FF & $\begin{array}{l}\text { PCE } \\
(\%)\end{array}$ \\
\hline \multirow[t]{5}{*}{$\begin{array}{l}\text { DPP- } \\
\text { glass }\end{array}$} & $\mathrm{PhCl}$ & no & 1.80 & 0.28 & 0.39 & $\begin{array}{l}0.18 \pm \\
0.02\end{array}$ \\
\hline & & $100^{\circ} \mathrm{C}$ & 2.45 & 0.28 & 0.40 & $\begin{array}{l}0.26 \pm \\
0.01\end{array}$ \\
\hline & $\mathrm{CHCl}_{3}$ & no & 1.73 & 0.41 & 0.41 & $\begin{array}{l}0.30 \pm \\
0.01\end{array}$ \\
\hline & & $80^{\circ} \mathrm{C}$ & 2.25 & 0.42 & 0.42 & $\begin{array}{l}0.41 \pm \\
0.01\end{array}$ \\
\hline & Toluene & $100^{\circ} \mathrm{C}$ & 2.66 & 0.39 & 0.39 & $\begin{array}{l}0.40 \pm \\
0.02\end{array}$ \\
\hline \multirow[t]{7}{*}{ PCBM } & $\mathrm{PhCl}$ & no & 3.06 & 0.40 & 0.30 & $\begin{array}{l}0.36 \pm \\
0.04\end{array}$ \\
\hline & & $100^{\circ} \mathrm{C}$ & 3.20 & 0.42 & 0.45 & $\begin{array}{l}0.44 \pm \\
0.01\end{array}$ \\
\hline & $\mathrm{CHCl}_{3}$ & no & 2.28 & 0.43 & 0.41 & $\begin{array}{l}0.39 \pm \\
0.02\end{array}$ \\
\hline & & $80^{\circ} \mathrm{C}$ & 2.30 & 0.43 & 0.43 & $\begin{array}{l}0.41 \pm \\
0.02\end{array}$ \\
\hline & Toluene & $100^{\circ} \mathrm{C}$ & 2.35 & 0.42 & 0.34 & $\begin{array}{l}0.30 \pm \\
0.03\end{array}$ \\
\hline & & $130^{\circ} \mathrm{C}$ & 2.68 & 0.46 & 0.38 & $\begin{array}{l}0.45 \pm \\
0.02\end{array}$ \\
\hline & & $150^{\circ} \mathrm{C}$ & 2.96 & 0.49 & 0.39 & $\begin{array}{l}0.52 \pm \\
0.05\end{array}$ \\
\hline
\end{tabular}

\section{Conclusions}

In summary, we report the first instance of organic photovoltaic cells where the active layer is an amorphous homogeneous blend composed of two small-molecule 
materials, including a new squarylium cyanine donor (SQglass), and two acceptors: DPP-glass and $\mathrm{PC}_{61} \mathrm{BM}$. Depending on the processing conditions, PCBM can undergo crystallization and phase segregation, allowing to compare the performances of the devices with and without phase segregation. The devices incorporating DPP-glass reached efficiencies up to $0.41 \%$, whereas the devices with PCBM reached maximal efficiencies of $0.44 \%$ for homogeneous blends, or $0.52 \%$ for phase-segregated blends. Although phase segregation of the donor and acceptor was found to result in higher efficiencies, it resulted in a performance enhancement of only $18 \%$, highlighting the fact that while electron transport is more efficient in phase-segregated bulk heterojunctions than in homogeneous blends in theory, the presence of defects in the former, and their absence in the latter, results in more closely similar performances than expected. Although the efficiencies reported herein are modest because of the low mobility of the donor, the concept presented herein will pave the way to the development of organic photovoltaic cells with improved glass-forming donor and acceptor materials.

\section{Acknowledgements}

The authors would like to acknowledge the Canadian Defence Academic Research Programme (CDARP) of RMC and the Natural Sciences and Engineering Research Council (NSERC) Discovery Grants program (RGPIN-2015-05485) and CREATE program (Novel Chiral Materials: An International Effort in Research and Education) for supporting this research. We would also like to thank Drs. René Gagnon and Philippe Venne (Université de Sherbrooke) for mass spectrometry analyses.

\section{Supporting Information}

DSC thermograms of compounds $\mathbf{2 - 4}$, cyclic voltammograms of compound 4, additional current-voltage curves for photovoltaic cells, calibrated data for PV cells, electron mobility measurement for compounds 4, NMR spectra of compounds 1-4.

\section{Notes and references}

‡ Marvin was used for drawing, displaying and characterizing chemical structures, substructures and reactions, Marvin 15.1.12, 2015, ChemAxon (www.chemaxon.com).

1 Bloking, J.T.; Han, X.; Higgs, A.T.; Kastrop, J.P.; Pandey, L.; Norton, J.E.; Risko, C.; Chen, C.E.; Brédas, J.-L.; McGehee, M.D.; Sellinger, A., Solution-Processed Organic Solar Cells with Power Conversion Efficiencies of $2.5 \%$ using Benzothiadiazole/Imide-Based Acceptors. Chem. Mater. 2011, 23, 5484-5490.

2 Cnops, K.; Rand, B.P.; Cheyns, D.; Verreet, B.; Empl, M.A.; Heremans, P., 8.4\% efficient fullerene-free organic solar cells exploiting long-range exciton energy transfer. Nat. Commun. 2014, 5, 3406.

3 Lin, Y.; Ma, L.; Li, Y.; Liu, Y.; Zhu, D.; Zhan, X., A
Solution-Processable Small Molecule Based on Benzodithiophene and Diketopyrrolopyrrole for HighPerformance Organic Solar Cells. Adv. Energ. Mater. 2013, 3 , 1166-1170.

4 Sun, D.; Meng, D.; Cai, Y.; Fan, B.; Li, Y.; Jiang, W. Huo, L.; Sun, Y.; Wang, Z., Non-Fullerene-Acceptor-Based Bulk-Heterojunction Organic Solar Cells with Efficiency over 7\%.J. Am. Chem. Soc. 2015, 137, 11156-11162.

5 Zhou, Y.; Ding, L.; Shi, K.; Dai, Y. Z.; Ai, N.; Wang, J.; Pei, J., A non-fullerene small molecule as efficient electron acceptor in organic bulk heterojunction solar cells. Adv. Mater. 2012, 24, 957-61.

6 Tang, Z.; Liu, B.; Melianas, A.; Bergqvist, J.; Tress, W.; Bao, Q.; Qian, D.; Inganas, O.; Zhang, F., A new fullerenefree bulk-heterojunction system for efficient high-voltage and high-fill factor solution-processed organic photovoltaics. Adv. Mater. 2015, 27, 1900-1907.

7 Li, G.; Zhu, R.; Yang, Y., Polymer Solar Cells. Nat Photon. 2012, 6, 153-161.

8 Dyakonov, V., The polymer-fullerene interpenetrating network: one route to a solar cell approach. Physica E 2002, 14 , 53-60.

9 Lloyd, M.T.; Mayer, A.C.; Subramanian, S.; Mourey, D.A.; Herman, D.J.; Bapat, A.V.; Anthony, J.E.; Malliaras, G.G., Efficient solution-processed photovoltaic cells based on an anthradithiophene/fullerene blend. J. Am. Chem. Soc. 2007, $129,9144-9149$.

10 Guerrero, A.; Garcia-Belmonte, G., Recent Advances to Understand Morphology Stability of Organic Photovoltaics. Nano-Micro Lett. 2016, 9.

11 Yang, X.; Loos, J.; Veenstra, S.C.; Verhees, W.J.; Wienk, M.M.; Kroon, J.M.; Michels, M.A.; Janssen, R.A., Nanoscale morphology of high-performance polymer solar cells. Nano Lett. 2005, 5, 579-583.

12 Chen, D.; Liu, F.; Wang, C.; Nakahara, A.; Russell, T.P., Bulk heterojunction photovoltaic active layers via bilayer interdiffusion. Nano Lett. 2011, 11, 2071-2078.

13 Hedley, G.J.; Ward, A.J.; Alekseev, A.; Howells, C.T.; Martins, E.R.; Serrano, L.A.; Cooke, G.; Ruseckas, A.; Samuel, I.D., Determining the optimum morphology in highperformance polymer-fullerene organic photovoltaic cells. Nat. Commun. 2013, 4, 2867.

14 Ng, A.; Liu, X.; To, C.H.; Djurisic, A.B.; Zapien, J.A.; Chan, W.K., Annealing of P3HT:PCBM blend film--the effect on its optical properties. ACS Appl. Mater. Interfaces 2013, 5 , 4247-4259.

15 Yip, H.-L.; Jen, A.K.Y., Recent advances in solutionprocessed interfacial materials for efficient and stable polymer solar cells. Energ. Env. Sci. 2012, 5, 5994 -6011.

16 He, Z.; Xiao, B.; Liu, F.; Wu, H.; Yang, Y.; Xiao, S.; Wang, C.; Russell, T.P.; Cao, Y., Single-junction polymer solar cells with high efficiency and photovoltage. Nat. Photon., 2015, 9, 174-179.

17 Holliday, S.; Li, Y.; Luscombe, C.K., Recent advances in high performance donor-acceptor polymers for organic photovoltaics. Progr. Polym. Sci. 2017, in press,

18 Anthony, J.E., Small-Molecule, Nonfullerene Acceptors for Polymer Bulk Heterojunction Organic Photovoltaics. Chem. Mater. 2011, 23, 583-590.

19 Kamm, V.; Battagliarin, G.; Howard, I. A.; Pisula, W.; Mavrinskiy, A.; Li, C.; Müllen, K.; Laquai, F., Polythiophene:Perylene Diimide Solar Cells - the Impact of Alkyl-Substitution on the Photovoltaic Performance. Adv. Energ. Mater. 2011, 1, 297-302.

20 Baffreau, J.; Leroy-Lhez, S.; Derbal, H.; Inigo, A.R.; Nunzi, J.-M.; Groeneveld, M.M.; Williams, R.M.; Hudhomme, P., Light-harvesting fullerenes for organic solar cells. Eur. Phys. 
J. Appl. Phys. 2007, 36, 301-305.

21 Walker, B.; Kim, C.; Nguyen, T.-Q., Small Molecule Solution-Processed Bulk Heterojunction Solar Cells. Chem. Mater. 2011, 23, 470-482.

22 Brabec, C.J.; Durrant, J.R., Solution-Processed Organic Solar Cells. MRS Bull. 2011, 33, 670-675.

23 Destouesse, E.; Chambon, S.; Courtel, S.; Hirsch, L.; Wantz, G. Solution-Processed Small-Molecule Bulk Heterojunctions: Leakage Currents and the Dewetting Issue for Inverted Solar Cells. ACS Appl. Mater. Interfaces 2015, 7, 24663-24669.

24 Duan, L.; Hou, L.; Lee, T.-W.; Qiao, J.; Zhang, D.; Dong, G.; Wang, L.; Qiu, Y., Solution processable small molecules for organic light-emitting diodes. J. Mater. Chem. 2010, 20, 6392 .

25 Adhikari, T.; Ghoshouni Rahami, Z.; Nunzi, J.-M.; Lebel, O., Synthesis, characterization and photovoltaic performance of novel glass-forming perylenediimide derivatives. Org. Electron. 2016, 34, 146-156.

26 Adhikari, T.; Nunzi, J.-M.; Lebel, O. Solid-state showdown: comparing the photovoltaic performance of amorphous and crystalline small-molecule diketopyrrolopyrrole acceptors. Org. Electron., submitted.

27 Wuest, J. D.; Lebel, O., Anarchy in the solid state: structural dependence on glass-forming ability in triazine-based molecular glasses. Tetrahedron 2009, 65, 7393-7402.

28 Eren, R.N.; Plante, A.; Meunier, A.; Laventure, A.; Huang, Y.; Briard, J.G.; Creber, K.J.; Pellerin, C.; Soldera, A.; Lebel, O., One ring to rule them all: effect of aryl substitution on glass-forming ability in mexylaminotriazine molecular glasses. Tetrahedron 2012, 68, 10130-10144.

29 Laventure, A.; Soldera, A.; Pellerin, C.; Lebel, O., Heads vs. tails: a double-sided study of the influence of substituents on the glass-forming ability and stability of aminotriazine molecular glasses. New J. Chem. 2013, 37, 38813889.

30 Kirby, R.; Sabat, R.G.; Nunzi, J.-M.; Lebel, O. Disperse and disordered: a mexylaminotriazine-substituted azobenzene derivative with superior glass and surface relief grating formation. J. Mater. Chem. C 2014, 2, 841-847.

31 Bennani, O.R.; Al-Hujran, T.A.; Nunzi, J.-M.; Sabat, R.G.; Lebel, O., Surface relief grating growth in thin films of mexylaminotriazine-functionalized glass-forming azobenzene derivatives. New J. Chem. 2015, 39, 9162-9171.

32 Wu, J.; Becerril, H.A.; Bao, Z.; Liu, Z.; Chen, Y; Peumans, P., Organic solar cells with solution-processed graphene transparent electrodes. Appl. Phys. Lett. 2008, 92, 263302 .

33 Kippelen, B.; Brédas, J.-L., Organic photovoltaics. Energ. Env. Sci. 2009, 2, 251-261.

34 Matsuno, T.; Kato, M.; Tsuchida, Y.; Takahashi, M.; Yaguchi, S.; Terada, S., Synthesis and Aromatase-Inhibitory Activity of Imidazoly-1, 3, 5-triazine Derivatives. Chem. Pharm. Bull. 1997, 45, 291-296.

35 Xue, Y.; Tian, J.; Tian, W.; Gong, P.; Dai, J.; Wang, X., Significant Fluorescence Enhancement of Spiropyran in Colloidal Dispersion and Its Light-Induced Size Tunability for Release Control. J. Phys. Chem. C 2015, 119, 20762-20772.

36 Gholamkhass, B.; Kiasari, N.M.; Servati, P., An efficient inverted organic solar cell with improved $\mathrm{ZnO}$ and gold contact layers. Org. Electron. 2012, 13, 945-953.

37 Adhikari, T.; Solanke, P.; Pathak, D.; Wagner, T.; Bureš, F.; Reed, T.; Nunzi, J.-M., T-Shaped Indan-1,3-dione derivatives as promising electron donors for bulk heterojunction small molecule solar cells. Opt. Mater. 2017, 69 , 312-317.

38 Pathak, D.; Wagner, T.; Adhikari, T.; Nunzi, J.-M.,
AgInSe 2 :PCBM:P3HT inorganic organic blends for hybrid bulk heterojunction photovoltaics. Synth. Metals 2015, 200, 102-108.

39 Kim, J.S.; Park, J.H.; Lee, J.H.; Jo, J.; Kim, D.-Y.; Cho, K., Control of the electrode work function and active layer morphology via surface modification of indium tin oxide for high efficiency organic photovoltaics. Appl. Phys. Lett. 2007, 91,112111 .

40 Garnier, F.; Yassar, A.; Hajlaoui, R.; Horowitz, G.; Deloffre, F.; Servet, B.; Ries, S.; Alnot, P., Molecular engineering of organic semiconductors: design of self-assembly properties in conjugated thiophene oligomers. J. Am. Chem. Soc. 1993, 115, 8716-8721.

41 Chen, G.; Sasabe, H.; Igarashi, T.; Hong, Z.; Kido, J., Squaraine dyes for organic photovoltaic cells. J. Mater. Chem. A 2015, 3, 14517-14534.

42 Wei, G.; Lunt, R.R.; Sun, K.; Wang, S.; Thompson, M.E.; Forrest, S.R., Efficient, ordered bulk heterojunction nanocrystalline solar cells by annealing of ultrathin squaraine thin films. Nano Lett. 2010, 10, 3555-3559.

43 So, S.; Choi, H.; Min Ko, H.; Kim, C.; Paek, S.; Cho, N.; Song, K.; Lee, J.K.; Ko, J., Novel unsymmetrical push-pull squaraine chromophores for solution processed small molecule bulk heterojunction solar cells. Sol. Energ. Mater. Sol. Cells 2012, 98, 224-232.

44 Yang, D.; Jiao, Y.; Yang, L.; Chen, Y.; Mizoi, S.; Huang, Y.; Pu, X.; Lu, Z.; Sasabe, H.; Kido, J., Cyanosubstitution on the end-capping group: facile access toward asymmetrical squaraine showing strong dipole-dipole interactions as a high performance small molecular organic solar cells material. J. Mater. Chem. A 2015, 3, 17704-17712.

45 Lee, Y.-D.; Lim, C.-K.; Kim, S.; Kwon, I.-C.; Kim, J. Squaraine-Doped Functional Nanoprobes: Lipophilically Protected Near-Infrared Fluorescence for Bioimaging. Adv. Funct. Mater. 2010, 20, 2786-2793.

46 Jiao, G.-S.; Loudet, A.; Lee, H.B.; Kalinin, S.; Johansson, L.B.-A.; Burgess, K., Syntheses and spectroscopic properties of energy transfer systems based on squaraines. Tetrahedron 2003, 59, 3109-3116.

47 Meunier, A.; Lebel, O., A Glass Forming Module for Organic Molecules: Making Tetraphenylporphyrin Lose its Crystallinity. Org. Lett. 2010, 12, 1896-1899.

48 Laventure, A.; De Grandpré, G.; Soldera, A.; Lebel, O.; Pellerin, C., Unraveling the interplay between hydrogen bonding and rotational energy barrier to fine-tune the properties of triazine molecular glasses. Phys. Chem. Chem. Phys. 2016 $18,1681-1692$

49 Tauc, J.; Grigorovici, R.; Vancu, A., Optical Properties and Electronic Structure of Amorphous Germanium. Phys. Stat. Sol. 1966, 15, 627-637.

50 Li, L.; Jacobs, D.L.; Bunes, B.R.; Huang, H.; Yang, X.; Zang, L., Anomalous high photovoltages observed in shish kebab-like organic p-n junction nanostructures. Polym. Chem. 2014, 5, 309-313.

51 Brabec, C.; Scherf, U.; Dyakonov, V., Organic photovoltaics: materials, device physics, and manufacturing technologies, John Wiley \& Sons, 2011.

52 Moliton, A.; Nunzi, J.-M., How to model the behaviour of organic photovoltaic cells. Polym. Internat. 2006, $55,583-600$

53 Nikitenko, S.; Mayorova, J.; Troshin, P.; Lyubovskaya, R.; Kaplunov, M., Photoluminescence quenching study of composites comprising novel fullerene-based acceptors and MDMO-PPV. Mol. Cryst. Liq. Cryst. 2007, 468, $239 /[591]-244 /[596]$.

54 E. Melito, A. Laventure, G. Aldea-Nunzi, C. Pellerin, E. Buncel, O. Lebel and J.-M. Nunzi, J. Mater. Chem. C, 2015 , 


\section{3, 4729-4736}

55 Hau, S.K.; Yip, H.-L.; Jen, A.K.Y., A Review on the Development of the Inverted Polymer Solar Cell Architecture. Polym. Rev. 2010, 50, 474-510.

56 Sahin, Y.; Alem, S.; de Bettignies, R.; Nunzi, J.M., Development of air stable polymer solar cells using an inverted gold-on-top anode structure Thin Sol. Films 2005, 476, 340343.

57 White, M.S.; Olson, D.C.; Shaheen, S.E.; Kopidakis, N.; Ginley, D.S., Inverted bulk-heterojunction organic photovoltaic device using a solution-derived $\mathrm{ZnO}$ underlayer. Appl. Phys. Lett. 2006, 89, 143517.

58 Gholamkhass, B.; Kiasari, N.M.; Servati, P., An efficient inverted organic solar cell with improved $\mathrm{ZnO}$ and gold contact layers. Org. Electron. 2012, 13, 945-953.

59 Garcia-Belmonte, G.; Bisquert, J., Open-circuit voltage limit caused by recombination through tail states in bulk heterojunction polymer-fullerene solar cells. Appl. Phys. Lett. 2010, 96, 113301.

60 Pandey, A.K.; Nunzi, J.M., Impact of selective thermal annealing on rubrene-C60 heterojunction solar cells, Synth. Metals 2012, 162, 2171-2175.

61 Derbal-Habak, H.; Bergeret, C.; Cousseau, J.; Nunzi, J.M., Improving the Current density $\mathrm{J}_{\mathrm{sc}}$ of organic solar cells P3HT:PCBM by structuring the photoactive layer with functionalized SWCNTs. Sol. Energ. Mater. Sol. Cells 2011 95, S53-S56. 
An organic photovoltaic cell with an amorphous, homogeneously blended active layer is reported.

This PV cell uses a novel glass-forming donor based on a squarylium cyanine core (SQ-glass), and a previously reported glass-forming diketopyrrolopyrrole acceptor (DPP-glass).

The photovoltaic performance of this cell was measured, and compared to that of cells with the active layer composed of SQ-glass and $\mathrm{PC}_{61} \mathrm{BM}$, both homogeneously blended and phase-segregated.

Efficiencies ranging from 0.41 to $0.56 \%$ were obtained. Interestingly, although phase segregation gave higher efficiencies, a homogeneous blend still yielded efficiencies that were close. Phase segregation resulted in a $18 \%$ increase. 


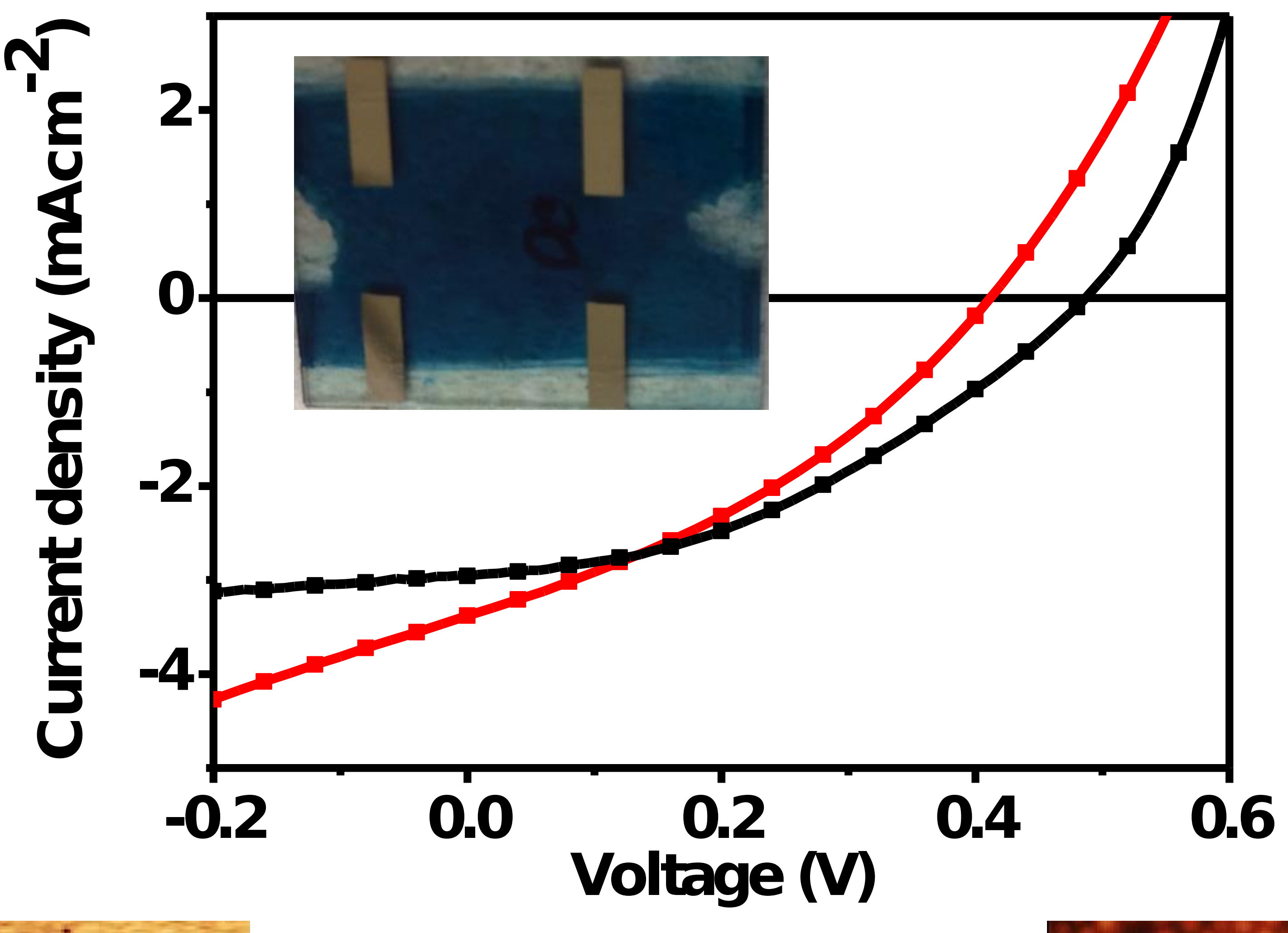

Phase-Segregated 